Robinson, S. G., J. Fraser, D. Catlin, S. M. Karpanty, J. Altman, R. Boettcher, K. Holcomb, C. Huber, K. Hunt, and A. Wilke. 2019. Irruptions: evidence for breeding season habitat limitation in Piping Plover (Charadrius melodus). Avian Conservation and Ecology 14(1):19. https://doi. org/10.5751/ACE-01373-140119

Copyright (C) 2019 by the author(s). Published here under license by the Resilience Alliance.

Research Paper

\title{
Irruptions: evidence for breeding season habitat limitation in Piping Plover (Charadrius melodus)
}

\author{
Samantha Robinson ${ }^{1}$, James Fraser ${ }^{1}$, Daniel Catlin ${ }^{1}$, Sarah Karpanty ${ }^{1}$, Jon Altman ${ }^{2}$, Ruth Boettcher ${ }^{3}$, Kevin Holcomb ${ }^{4}$, Coral Huber \\ ${ }^{5}$, Kelsi Hunt ${ }^{1}$ and Alexandra Wilke ${ }^{6}$ \\ ${ }^{1}$ Department of Fish and Wildlife Conservation, Virginia Tech, Blacksburg, VA, 24061, USA, ${ }^{2}$ Cape Lookout National Seashore, \\ National Park Service, ${ }^{3}$ Virginia Department of Game and Inland Fisheries, ${ }^{4}$ Chincoteague National Wildlife Refuge, U.S. Fish \& \\ Wildlife Service, ${ }^{5}$ Omaha District, United States Army Corps of Engineers, ${ }^{6}$ The Nature Conservancy
}

\begin{abstract}
Effective management of wildlife populations requires identification of the factors limiting their growth. The Piping Plover (Charadrius melodus) is an imperiled, disturbance-dependent, shorebird species that nests on broad, sparsely vegetated beaches, sandbars, and lakeshores. In areas minimally affected by human use, plover habitat loss occurs through vegetation encroachment and erosion. Alternatively, habitat availability may be increased by sand deposition caused by storm- or flood-induced sediment transport or scouring that removes vegetation, or by receding lake levels. To test the hypothesis that plover populations are limited by available breeding habitat, we estimated the amount of habitat available before and after four significant storm and flooding events (i.e., disturbance) by classifying pre- and postdisturbance aerial imagery. We then evaluated the population changes that occurred after disturbance-related habitat alterations. Additionally, we report on population changes from four population increases that occurred after habitat creation events for which we did not have imagery suitable for classification. The storm and flood effects considered were those from hurricanes and nor'easters on barrier islands of Virginia, North Carolina, New York, and Maryland, USA, and those from floods and high water output from the Gavins Point Dam on the Missouri River between South Dakota and Nebraska, USA. The amount of nesting habitat increased $27-950 \%$ at these sites, and plover populations increased overall $72-622 \%$ after these events (increase of 8-217 pairs in 3 to 8 years after the disturbance, average $12-116 \%$ increase annually). The demographic changes were driven by productivity in some cases and probably by increases in immigration in others, and occurred simultaneously with regional increases. Our results support our hypothesis that the focal plover populations were at or near carrying capacity and are habitat limited. Currently, human interventions such as beach stabilization, the construction of artificial dunes, and dams reduce natural disturbance, and therefore, the carrying capacity, in many plover breeding areas. If these interventions were reduced or modified in such a way as to create and improve habitat, plover populations would likely reach higher average numbers and the potential for achieving recovery goals would be increased.
\end{abstract}

\section{Irruptions : preuves de la limitation de l'habitat pendant la saison de reproduction du pluvier siffleur (Charadrius melodus)}

RÉSUMÉ. La gestion efficace des populations de faune sauvage requiert l'identification des facteurs qui limitent leur croissance. Le pluvier siffleur (Charadrius melodus) est une espèce d'oiseaux de rivage menacée, dépendante des perturbations, qui niche sur de grandes plages à la végétation clairsemée, sur les bancs de sable et au bord des lacs. Dans les régions peu affectées par la présence humaine, la perte d'habitat du pluvier est due à l'empiètement de la végétation et à l'érosion. La disponibilité de l'habitat peut aussi être accrue par les dépôts de sable causés par les transports de sédiments induits par les tempêtes ou les inondations, par l'affouillement qui élimine la végétation ou par la baisse du niveau des lacs. Pour tester l'hypothèse selon laquelle les populations de pluvier sont limitées par l'habitat de reproduction disponible, nous avons estimé la surface d'habitat disponible avant et après quatre événements majeurs de tempête et d'inondation (c'est-à-dire des perturbations) en classant les images aériennes avant et après les perturbations. Nous avons ensuite évalué l'évolution des populations survenue après les altérations de l'habitat liées aux perturbations. En outre, nous rapportons sur les changements de population par suite de quatre augmentations de la population intervenues après des événements de création d'habitat pour lesquels nous ne disposions pas d'imagerie adéquate pour établir un classement. Les effets des tempêtes et des inondations considérées étaient ceux d'ouragans et de tempêtes sur les îles barrières de Virginie, de Caroline du Nord, de New York et du Maryland, aux États-Unis, et ceux des inondations provoquées par le débit d'eau élevé du barrage de Gavins Point, sur le Missouri, entre le Dakota du Sud et le Nebraska, également aux États-Unis. La superficie de l'habitat de nidification a augmenté de 27 à $950 \%$ sur ces sites et les populations de pluviers ont augmenté globalement de 72 à $622 \%$ après ces événements (le nombre de couples est passé de 8 à 217 en 3 à 8 ans à la suite de ces perturbations, soit une augmentation moyenne annuelle de 12 à $116 \%$ ). Les évolutions démographiques résultaient de la productivité dans certains cas et probablement d'augmentations des migrations dans d'autres cas, et correspondaient à des augmentations régionales. Nos résultats viennent étayer notre hypothèse selon laquelle les populations de pluviers observées étaient à leur capacité porteuse et sont limitées par l'habitat. Actuellement, les interventions humaines comme la stabilisation des plages, 
la construction de dunes artificielles et de barrages réduisent les perturbations naturelles et en conséquence, la capacité porteuse, dans de nombreuses régions de reproduction des pluviers. Si ces interventions étaient réduites ou modifiées de manière à créer et à améliorer l'habitat, les populations de pluviers atteindraient probablement des nombres moyens plus élevés et le potentiel de réalisation des objectifs de rétablissement des populations serait plus élevé.

Key Words: Charadrius melodus; density-dependence; eCognition; habitat limitation

\section{INTRODUCTION}

Habitat loss is a pervasive cause of population declines (e.g., Dolman and Sutherland 1995, Flockhart et al. 2015). When habitat is lost, or its suitability declines, density-dependent demographic responses can result in population declines (Turchin 1990, Newton 1998, Brook and Brashaw 2006, Martin 2015). When an increasing population nears the level the habitat can support, often referred to as the carrying capacity of the habitat, some or all vital rates change. Birth rates and immigration may decline, and death rates and emigration rates may increase (Nicholson 1933, Newton 1998), causing population numbers to settle near the carrying capacity. These demographic rates may be mediated by individual-specific changes related to habitat, as when transformation of body condition affects survival or clutch size, which then affects the number of local recruits available to breed in the following year (Cooch et al. 1989, Francis et al. 1992, Marra et al. 2015). If densities in available habitat limit a population, improvement of existing habitat or creation of new habitat should increase carrying capacity, thus resulting in population growth. Alternatively, some species declines have been driven by density-independent factors, including climate (Putman et al. 1996), pesticides (Grier 1982, Buehler 2000, White et al. 2002, Shields 2014), poisons (Nadjafzadeh et al. 2013), and overharvest (Chan et al. 2014, Wittemyer et al. 2014, Hamilton et al. 2015, Licht et al. 2015). In such cases, when habitat availability remains abundant or is restored, and reproduction and mortality return to more normal levels, populations rebound.

Failure to discern what limits a population can lead to ineffective conservation interventions. For example, if a population is limited by habitat or predators, but the primary management strategy is to increase productivity by reducing human disturbance, management may be ineffective without concurrent habitat creation or predator reduction (Baudains and Lloyd 2007). On a barrier island in North Carolina, USA, mammalian predators were hypothesized to be contributors to American Oystercatcher (Haematopus palliates) population change through nest and chick predation, but after a predator removal experiment, no relationship was detected between predator numbers and nest survival (Schulte and Simons 2016, Stocking et al. 2017). Instead, increases in nest success may have been driven by increases in habitat quality following Hurricane Isabel (Schulte and Simons 2016). Specific drivers of vital rates and abundance vary by species and location; therefore, it is important to assess them on a speciesand location-specific basis and at appropriate scales. Identification of broad-scale or range-wide drivers could help target effective management tasks that could lead to regional increases or even recovery.

The Piping Plover (Charadrius melodus; hereafter plover) is a temperate breeding shorebird that was federally listed in the United States as threatened and endangered in 1986 (USFWS 1985). The species has experienced broad-scale habitat loss throughout its range. Plovers are territorial and defend nesting sites (Elliott-Smith and Haig 2004). In general, plover habitat comprises sparsely vegetated or open dry sand or gravel for nesting and moist sand for foraging (Burger 1987, Elliott-Smith and Haig 2004, Fraser et al. 2005). If breeding habitats are not periodically disturbed by storms, floods, or human interventions, vegetation can quickly overcome sandy habitats and render them unavailable for plovers (Gieder et al. 2014, Zeigler et al. 2017). Habitat loss on the Atlantic Coast of the United States has been attributed to increased development. There, infrastructure has replaced natural habitats. Moreover, to protect this infrastructure, shorelines have been manipulated in ways that inhibit natural beach renewal processes (Wilcox 1959, USFWS 1996). In the Great Plains, river management through dams, reservoirs, and channelization has reduced available habitat for plovers on prairie rivers (Catlin et al. 2015).

Since being federally listed, range-wide productivity monitoring has been a major component of assessing the success of recovery actions, especially in human-populated areas (Hecht and Melvin 2009a). Plover monitoring generally consists of frequent surveys to locate territorial adults and nests and to determine the success of hatched chicks (Hecht and Melvin 2009a). Despite intensive monitoring, management, and research, plover populations have not met the recovery goals set by the U.S. Fish and Wildlife Service (USFWS), potentially because plovers are limited by the amount and quality of available habitat on the landscape (Hecht and Melvin 2009b). However, these high-quality, long-term monitoring data may be useful to assess the mechanisms of population limitation for plovers across the breeding range.

The mechanisms of density-dependent limitation in plovers may be varied because they can involve density-dependent changes in more than one vital rate (birth, death, immigration, and emigration). When below carrying capacity, reproductive output plus immigration should be higher than emigration plus mortality, but as a population nears carrying capacity, these vital rates may change, slowing the population increase or causing a decline (Hixon et al. 2002). For example, increases in density can increase the likelihood of detection of nests and chicks by predators, thereby reducing reproductive output (Catlin et al. 2011b). Plover territoriality also directly limits the maximum number of breeding pairs the habitat can support (Cairns 1982). An increase in density can reduce the immigration rate or increase the emigration rate by limiting the number of available territories, thereby reducing the population's growth rate (Catlin et al. 2016).

Crowding effects can reduce reproductive output because incoming birds may need to settle in lower quality habitats, thereby reducing the per capita reproductive output of the population (Pulliam 1988). Alternatively, the main effect of habitat quality on plovers may be on density, reducing reproductive output by competition for food, and increasing predation and antagonistic interactions (Cohen et al. 2009, Catlin 
et al. 2011a). Higher quality habitat tends to be closer to moist foraging substrate, specifically, habitats with lower wave energy and abundant invertebrate prey (Elias et al. 2000, Cohen et al. 2009, Walker et al. 2019), but birds can settle in areas of lower quality habitat and therefore should exhibit lower productivity or survival on average.

Discerning the causes of population change, and especially the role of density dependence, can be challenging with the monitoring data that are obtained for most plover populations (Hecht and Melvin 2009a). For breeding plovers and other beachnesting birds, the relationship between reproduction and habitat can be confounded by predation and human disturbance (Maslo et al. 2019). For example, on Fire Island, New York, USA, 42\% of geomorphically suitable habitat was made unsuitable because of intensive beach driving (Walker et al. 2019). In some areas, habitat creation and improvement have been used for plover recovery (Catlin et al. 2015); in others, predation has been identified as a primary limiting factor, and lethal predator management has been used (Patterson et al. 1990, Cohen et al. 2009, Hecht and Melvin 2009a, Catlin et al. 2011a). However, in many areas, the primary cause of population suppression and decline is unclear and difficult to identify. If, instead of predators or other factors, the amount and quality of available habitat is the primary factor limiting plover numbers (Norris et al. 2004), this could be indicated by observing population numbers before and after habitat creation. Local population changes related to density may not directly affect the regional population, however, especially if immigration is the primary driver of increase. To determine whether local immigration is a function of birds moving to new habitat (Kokko and Sutherland 2001) or a result of a regional increase, local population change can be compared to regional population trends. If population increase on a small scale also corresponds to population increases on a broader scale, that would be systematic evidence of a population-level effect of a release of density.

Stochastic events such as hurricanes, nor'easters, and floods can create and improve plover habitat and initially reduce nesting densities by washing away vegetation and by shifting and exposing sand for nesting habitat (Cohen et al. 2009, Hunt et al. 2018, Walker et al.2019). Additionally, these events can create or expose highly productive foraging habitats (Le Fer et al. 2008, Cohen et al. 2009), thereby increasing habitat quality and presumably the carrying capacity. In both cases, if plovers are at the carrying capacity of their habitat and are limited mainly by availability and quality of habitat for breeding territories, a stochastic, density-independent event that creates or exposes new habitat or improves the quality of existing habitat should be followed by increases in plover populations through immigration, reproductive output, and survival. We hypothesize that if breeding habitat is limiting plover populations, when habitat increases so does the carrying capacity, and thus, the population should increase. To test our hypothesis, we reviewed existing information on the response of plover populations to habitatcreating events and used plover data from across the breeding range to investigate the relationship between habitat creation from storm and flood events, plover pair counts, and productivity.

\section{STUDY AREAS}

To assess the relationship between habitat and plover populations, we selected study areas in the United States for which we knew that long-term plover monitoring data existed, and areas we knew had been affected by events such as floods or storms, which tend to create habitat in disturbance-dependent systems. Some of the events have been studied previously, such as the effect of Hurricane Isabel on Atlantic Coast plovers (Boettcher et al. 2007, Schulte and Simons 2016) and the effect of Missouri River flooding on Great Plains plovers (Hunt et al. 2018). All study areas had some degree of predator reduction within the chosen focal periods, either for plover management or for sport hunting, and also had intensive management of public use or limited human access.

\section{Cape Lookout National Seashore, North Carolina}

Cape Lookout National Seashore is a $90-\mathrm{km}$ chain of barrier islands off the coast of North Carolina (Hillman et al. 2012). Plovers in North Carolina nest in coarse, shelly substrates and sandy overwash habitats (Cooper 1990, Kwon et al. 2018). Hurricane Isabel made landfall on Cape Lookout on 18 September 2003, resulting in substantial changes to the environment (Sheng et al. 2010). Plovers on Cape Lookout are distributed patchily along the island, and we selected a $5.5-\mathrm{km}$ section that was centered on Ophelia Inlet, which was created by Hurricane Ophelia in September of 2005 (Fig. 1).

\section{Cedar, Wreck, and Metompkin islands, Virginia}

Cedar (9.5 km long), Metompkin (10 km), and Wreck (6 km) islands are barrier islands off the coast of the lower Delmarva Peninsula in Virginia, and we classified and examined plover pair counts for the entirety of each island (Fig. 1). Plovers in Virginia nest on broad beaches with sand-shell flats (Boettcher et al. 2007). Hurricane Isabel substantially affected much of Virginia, despite not directly striking the islands (Boettcher et al. 2007). Many of the dry sand areas of Cedar, Wreck, and Metompkin islands are connected to marsh, creating moist sand between dry sand and marsh habitats, which can be attractive to foraging plovers. For pre- and post-Isabel comparison, we combined Cedar and Metompkin islands because they are adjacent (Fig. 1).

\section{Missouri River, Gavins Point reach, South Dakota and Nebraska}

The Gavins Point Reach of the Missouri River extends $95 \mathrm{~km}$ south from the Gavins Point Dam (Fig. 1), and we classified imagery and examined plover pair counts for the entire reach. The Gavins Point Reach is the last free-flowing section of the Missouri River, below which the river is channelized. Plovers on the Gavins Point Reach nest on open and sparsely vegetated sandbars (Catlin et al. 2015, Hunt et al. 2018). We used data from two habitatcreating events on the Missouri River. The first event was flooding and high water events between 1996 and 1997 (http://www.nwdmr.usace.army.mil/rcc/projdata/gapt.pdf). The second event was flooding and high water events that encompassed portions of the 2010 and 2011 breeding seasons (USACE 2012, Hunt et al. 2017, 2018). Flooding and high water levels were related to above- 
Fig. 1. Map of the contiguous United States showing the six study areas in which we investigated Piping Plover population irruptions following habitat-creating events. The westernmost site was located on the Missouri River below Gavins Point Dam, with irruptions from 1994-2000 and 2009-2015. On the Atlantic Coast, there were six irruption events: three on the barrier islands of Virginia (Metompkin, Cedar, and Wreck islands) from 2001-2008; one on Cape Lookout National Seashore from 20022008; one on Assateague Island, Maryland, from 1990-1997; and two on Westhampton Island, New York, from 1937-1947 and 1992-2000.

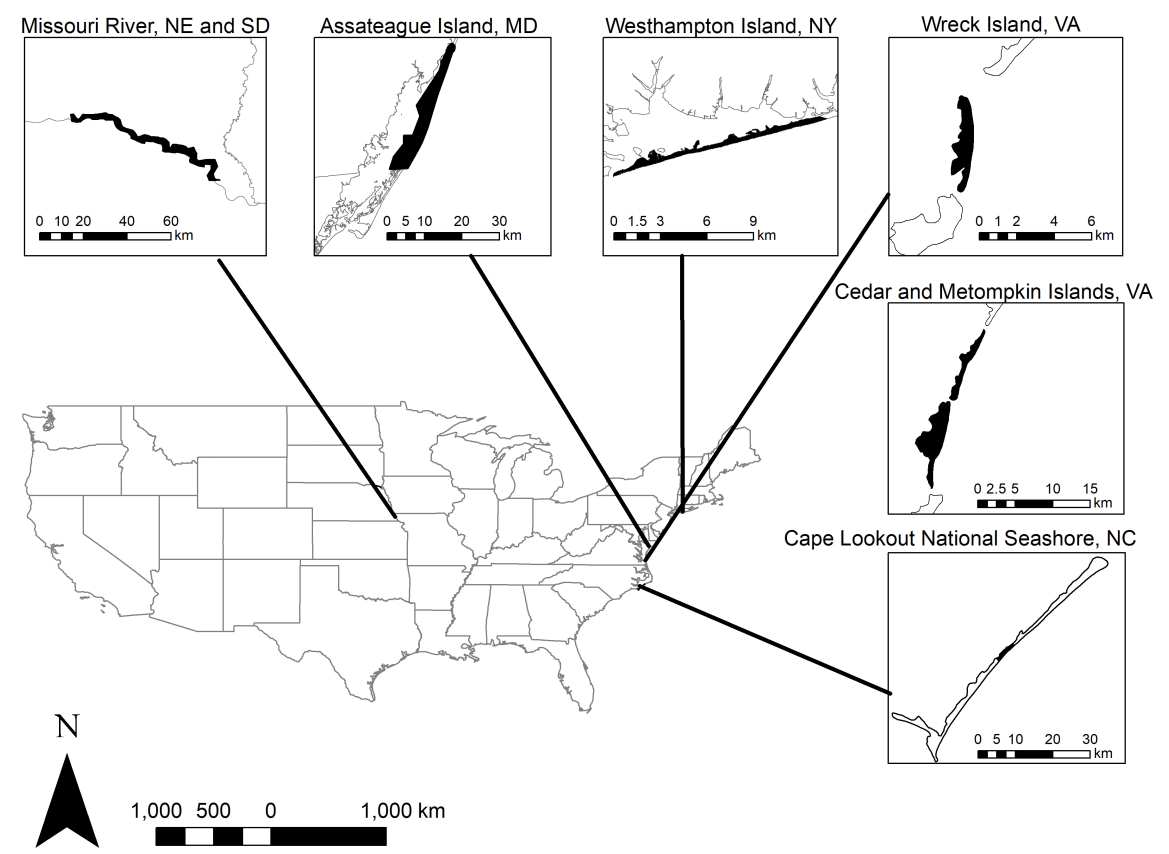

average snowpack and rainfall (USACE 2012). These two events were the highest outflow from the dam since its completion in 1957 (U.S. Army Corps of Engineers, unpublished data).

\section{Westhampton Island, New York}

Westhampton Island is a barrier island off the south shore of Long Island, New York, currently bounded on the western end by Moriches Inlet (Fig. 1). On Westhampton Island, plovers nest on sparsely vegetated ocean and bayward sandy beaches (Cohen et al. 2006). Several storms have affected the plover nesting habitat on Westhampton Island, but most notable are the hurricane of 1938 (Wilcox 1959) and a large nor'easter in December 1992 (Cohen et al. 2009). The hurricane of 1938 near Moriches Inlet increased nesting sand habitat by overwashing dunes and also created a new inlet, which increased bayside foraging access for chicks along $3.5 \mathrm{~km}$ of the island (Wilcox 1959). The nor'easter in 1992 created a large sand spit on the bayward side of the island and removed buildings, which increased bay access and nesting habitat along $8.4 \mathrm{~km}$ of the island for several years following the storm (Cohen et al. 2009).

\section{Assateague Island, Maryland}

Assateague Island is a $59 \mathrm{~km}$ long barrier island off the eastern coast of Maryland and Virginia (Gieder et al. 2014). It encompasses Assateague Island National Seashore and the majority of the nesting habitat for plovers in Maryland; thus, we used the Maryland census pair counts to examine population change (Fig. 1; A. Hecht, personal communication). Nesting habitat for plovers in Maryland includes primarily sparsely vegetated oceanfront beaches, with occasional bay access due to overwash processes (Patterson et al. 1991, Loegering and Fraser 1995, Schupp et al. 2013). Several storms in the early 1990s overwashed vegetation and created plover nesting habitat on Assateague Island until stabilization efforts reduced the probability of overwash on the island in the late 1990s, leading to vegetation encroachment and a decline in suitable habitat (Schupp et al. 2013).

\section{METHODS}

\section{Imagery acquisition}

We obtained imagery from as close in time as possible before each event. Immediately following habitat-creating events, there is typically extensive wet sand remaining from flooding and overwash. Much of the wet sand later dries to become open dry sand nesting habitat, but for image classification purposes, it would be excluded as nesting habitat if imagery immediately following the event were used. Therefore, for after each event, we selected imagery from $>1$ year postevent to allow short-term effects of the storm, such as extensive moist sand and soft sand covering low-lying vegetation, to settle. 
For Cape Lookout National Seashore, we obtained imagery from Google Earth Pro (Google LLC, Mountain View, California, USA). To georeference the imagery, we placed markers on four corners of the image and recorded the latitude and longitude. We then imported the imagery into ArcGIS 10.4 (ESRI, Redlands, California, USA) and georeferenced it using the four corner locations. Our prestorm image was from February 2003, several months before Hurricane Isabel. Our post-Isabel image was from July 2006, the third plover breeding season following the storm.

For the Virginia barrier island sites, we acquired imagery preIsabel from the Virginia Base Mapping Program, 0.61-m resolution (Febuary-April 2002; direct download from U.G. Geological Survey Earth Explorer: https://earthexplorer.usgs. gov/). Post-Isabel imagery was from the National Agriculture Imagery Program, 2-m resolution (U.S. Department of Agriculture 2016). The post-Isabel imagery for Cedar and Metompkin islands is from June 2005, and for Wreck Island is from May 2006 (U.S. Department of Agriculture 2016).

For the Missouri River, we used pan-sharpened multispectral QuickBird 1-m resolution imagery from 2009 and 2014 (DigitalGlobe Inc., Sunnyvale, California, USA). Imagery was collected between July and September in both years.

For the remainder of the sites, comparable high-resolution images corresponding with the timing of events was not available for classification. Therefore, we discuss the population changes following events similar to those described here for which we do have habitat, but without estimation of area of nesting habitat or plover density.

\section{Image classification}

For all of the irruptive events we studied and for which we had high-resolution imagery, it was clear from visual interpretation of the imagery that there was more dry sand following events that overwashed the islands and sandbars. However, to estimate the density of plovers, we needed to estimate the amount of nesting habitat available for plovers. To classify imagery, we used eCognition Essentials (Trimble, Westminster, Colorado, USA), an object-based classification software. We classified each image into 5 to 10 classes, depending on apparent spectral values within the imagery, and collapsed the classification into four classes: dry sand, moist sand, vegetation, and water. We clipped each image to the ocean mean high water line to reduce classification error caused by the similar spectral signature of bright dry sand and waves.

Classifications of imagery collected outside of the growing season, such as in February or March, are likely to underestimate the amount of vegetation during much of the breeding season, but they may better represent the conditions that birds find when they arrive on the breeding grounds than would imagery collected during the growing months (i.e., June or July). Because fine-scale imagery is not readily available for all years or seasons, the timing of imagery needs to be considered when comparing among months and years. For both Cape Lookout and the Virginia barrier islands, the prehurricane imagery was collected during the winter and early spring (February-April) before the growing period. The postevent imagery for all sites was collected during the growing season (May-August). Therefore, there was likely more dry sand created than we are estimating.
The Missouri River imagery was classified using Definiens Developer Software (Trimble Inc., Westminster, Colorado, USA). We grouped the land-cover classes of the classified imagery into nesting habitat (dry sand, dry sand-sparse vegetation, moist sand, moist sand-sparse vegetation; Strong 2012), vegetation, water, and other (e.g., clouds, unclassified, development).

We randomly selected 200 polygon objects from each image to estimate classification error, following methods of Radoux et al. (2011). Although it was important that our images were classified accurately, our main interest was that the dry sand classification was accurate because that area was considered available for plover nesting.

\section{Piping Plover data}

We obtained nesting information for all of the study areas from the agencies that monitor populations of Piping Plover at those sites, i.e., The Nature Conservancy, Virginia Department of Game and Inland Fisheries, United States Fish and Wildlife Service, United States Army Corps of Engineers, and National Park Service. Plover nests typically were found by visually searching an area or by observing nesting activities such as defensive or parental behaviors. Nests were monitored at varying intervals until hatch or failure. We collected nest locations using hand-held Global Positioning System units. It is possible that nests and pairs were missed; however, we assumed that any bias would be systematic within sites. If a nest hatched, we monitored chicks until they could no longer be found or until chicks fledged. We used pair or adult counts from 2-3 years before, and 3-5 years after each habitat-creating event to examine plover abundance at all sites. We also calculated the mean percent increase for each site during the years the population was increasing. We also acquired information regarding regional population change and reproductive output for each site, to better inform the effect of the focal events on overall plover population change and progress toward recovery goals.

The reproductive output (total number of chicks fledged divided by the number of pairs, chicks/pair) was used as an index for annual productivity. We used the number of chicks per pair to evaluate reproductive output for each site and evaluated it in reference to the estimated productivity needed for a stationary population, which is used as an average recovery threshold for Atlantic Coast plovers (1.2 chicks/pair; Melvin and Gibbs 1996). Finally, where applicable, we calculated nesting density as the number of pairs per unit area (pairs/ha) using the nesting habitat estimate from our habitat classifications and the pair counts in the year of our classified imagery. For irruption events occurring prior to the 2000s, we lacked both high-resolution plover data and high enough resolution imagery to classify for plover nesting. Therefore, we present these population increases that occurred after habitat-creating events as additional evidence for habitat limitation but cannot estimate habitat change.

\section{RESULTS}

Across all sites, the percentage of training samples correctly classified was $87.6-98.7 \%$ for dry sand polygons. Overall accuracy was between $68.9 \%$ and $95.3 \%$, with most misclassification occurring between moist sand and vegetation. 


\section{Cape Lookout, North Carolina}

Nesting habitat in the study site at Cape Lookout increased $27 \%$ between 2003 (78.6 ha) and 2006 (100.1 ha). Following Hurricane Isabel, dry sand nesting habitat extended from the ocean intertidal to the bayside intertidal, whereas previously, access for a walking plover chick to the bayside intertidal was mostly impeded by vegetation (Fig. 2). In the breeding season prior to Isabel, the summer of 2003, the Ophelia Inlet study area had only five pairs. There were 20 pairs in the Ophelia Inlet area in 2006, a $300 \%$ increase, and 26 in 2008, a 420\% increase (Fig 3). During the period of population increase, the average annual increase was $41 \%$ (standard error $[\mathrm{SE}]=11.2 \%$ ). Pair density increased from $0.051 \mathrm{pairs} / \mathrm{ha}$ in dry sand nesting habitat in 2003 to 0.24 pairs/ ha in 2006. Reproductive output in the Ophelia Inlet study area prior to Hurricane Isabel never exceeded the estimated value required to maintain a stationary population for Atlantic Coast plovers (1.2 chicks/pair; Fig. 4). Reproductive output following the storm was at or near what is required for a stationary population (1.10-1.23), but dropped well below the estimated value needed for stationarity after 2006. Following Hurricane Isabel, the entire population of North Carolina increased $167 \%$, from 24 pairs in 2003 to 64 pairs in 2008 (USFWS 2017). Regionally, from North Carolina to Delaware, reproductive output was higher than that required to maintain a stationary population prior to and following Hurricane Isabel (1.22-1.95).

Fig. 2. Sattelite images of Cape Lookout, North Carolina, around Ophelia Inlet, from before Hurricane Isabel in 2003 (left) and after Hurricane Isabel in 2006 (right). Land cover classification from eCognition is overlaid on the images. Hurricane Isabel occurred in the fall of 2003.

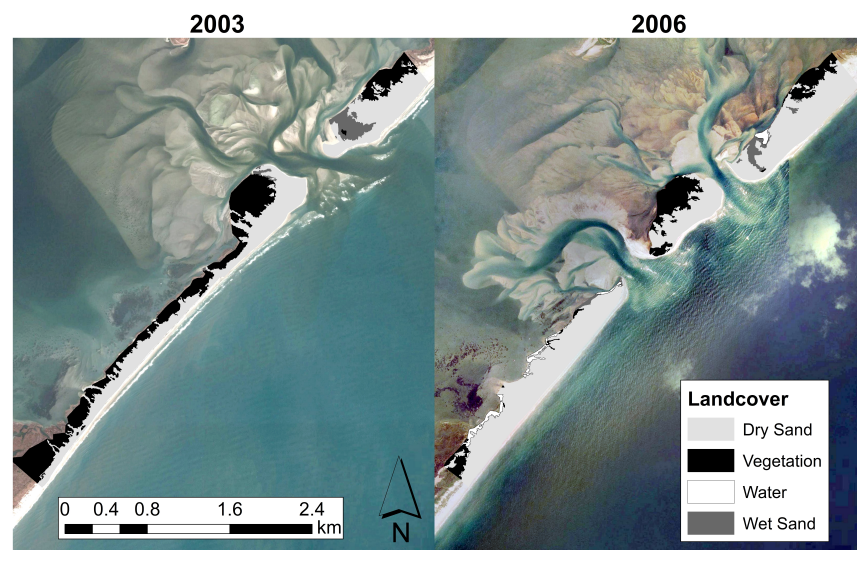

\section{Cedar and Metompkin islands, Virginia}

On Cedar and Metompkin islands, dry sand habitat increased from 229.7 ha in 2002 before Hurricane Isabel to 293.1 ha in 2005, 2 years after Hurricane Isabel (27.6\% increase; Table 1; Fig. A1.1 and A1.2). Corresponding with the habitat increase, pairs on Cedar and Metompkin increased from 57 pairs in 2003 to 98 pairs in 2008 (72\% increase; Fig. 3). While the population was increasing after Hurricane Isabel, the average annual increase was $11.8 \%(\mathrm{SE}=4.6 \%)$. Pair density increased from $0.23 \mathrm{pairs} / \mathrm{ha}$ in 2002 to 0.29 pairs/ha in 2005. Reproductive output on Cedar and
Metompkin Islands was above that required for a stationary population in the breeding season prior to Hurricane Isabel and remained above this level for 3 years following the hurricane (1.392.03 chicks/pair; Fig. 4). Similar to Cedar and Metompkin islands, the entire Virginia population increased $68 \%$, from 114 pairs in 2003 to 192 in 2005, following Hurricane Isabel (Boettcher et al. 2007).

Fig. 3. Pair counts over time for eight case studies of Piping Plover population irruption following habitat-creating events. Vertical dashed lines indicate the timing of the habitat-creating event.
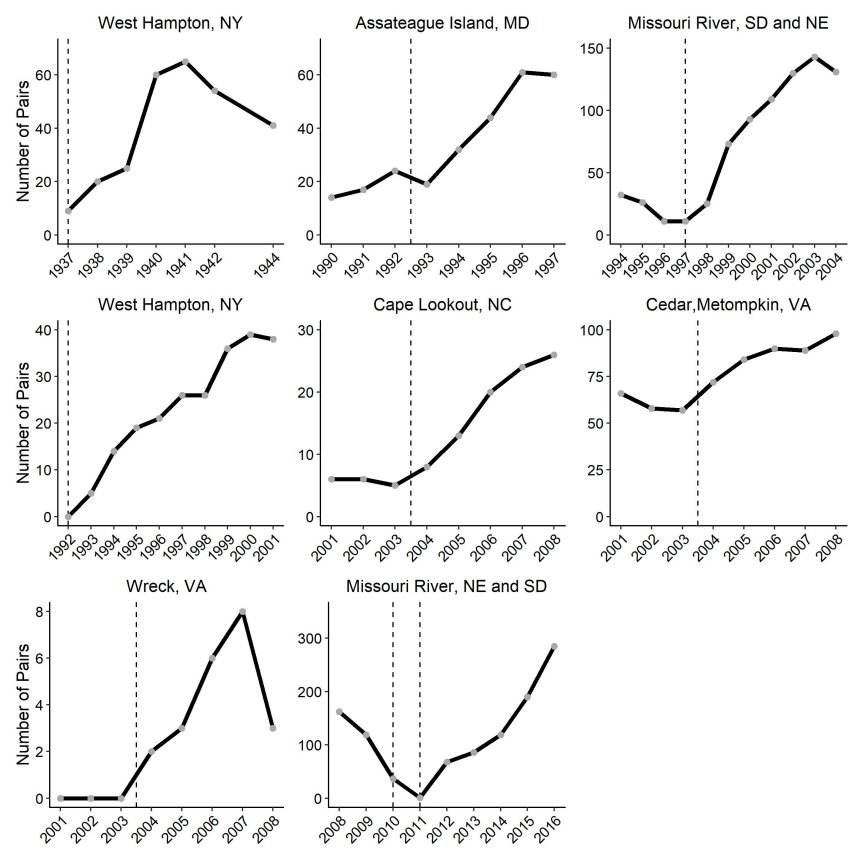

Fig. 4. Productivity (chicks/pair) over time for six irruption case studies following disturbance-creating events. The horizontal dotted line represents the estimated reproductive output required for stationarity (1.2 chicks/pair). Vertical dashed lines indicate the approximate timing of the disturbance-creating events. Productivity data are missing from the Missouri River in 2010 because of incomplete monitoring following high water events.

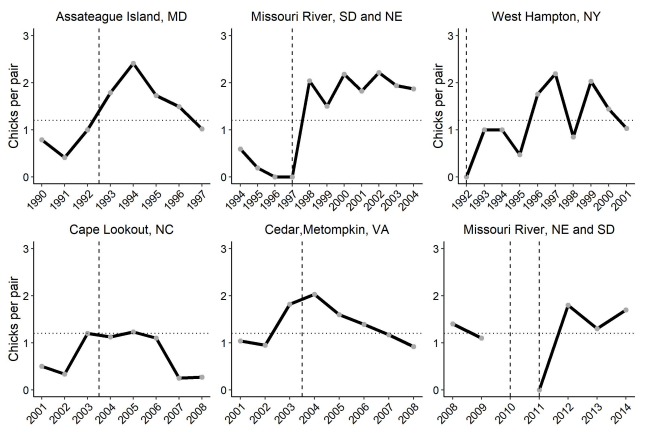


Table 1. Pair counts, potential nesting habitat from classified imagery, and nesting density for six study areas in which we investigated Piping Plover irruptions following habitat-creating events. Years shown are years for which we classified imagery before and after habitat-creating events (hurricanes and floods).

\begin{tabular}{|c|c|c|c|c|c|}
\hline Study Area & Year of event & Year of classification & $\begin{array}{c}\text { Number of } \\
\text { pairs }\end{array}$ & $\begin{array}{c}\text { Potential nesting } \\
\text { habitat (ha) }\end{array}$ & $\begin{array}{l}\text { Nesting density (pairs } \\
\text { ha) }\end{array}$ \\
\hline \multirow[t]{2}{*}{ Cape Lookout } & 2003 & 2003 & 5 & 78.6 & 0.062 \\
\hline & & 2006 & 20 & 100.1 & 0.20 \\
\hline \multirow[t]{2}{*}{ Cedar and Metompkin islands } & 2003 & 2002 & 53 & 229.7 & 0.23 \\
\hline & & 2005 & 84 & 293.1 & 0.29 \\
\hline \multirow{2}{*}{ Wreck Island } & 2003 & 2002 & 0 & 32.0 & 0 \\
\hline & & 2006 & 6 & 73.1 & 0.082 \\
\hline \multirow[t]{2}{*}{ Gavins Point Reach (2000s) } & 2010,2011 & 2009 & 119 & 119.2 & 1.00 \\
\hline & & 2014 & 119 & 1250.9 & 0.095 \\
\hline \multirow[t]{2}{*}{ Gavins Point Reach (1990s) } & 1997 & 1996 & 11 & N/A & N/A \\
\hline & & 2000 & 93 & N/A & N/A \\
\hline \multirow[t]{2}{*}{ Westhampton (1930s) } & 1938 & 1937 & 9 & N/A & N/A \\
\hline & & 1941 & 65 & N/A & N/A \\
\hline \multirow[t]{2}{*}{ Westhampton $(1990 \mathrm{~s})^{\dagger}$} & 1992 & 1992 & 0 & 22.3 & 0 \\
\hline & & 2000 & 38 & 39.9 & 1.05 \\
\hline \multirow[t]{2}{*}{ Assateague Island } & 1992 & 1990 & 14 & N/A & N/A \\
\hline & & 1997 & 60 & N/A & N/A \\
\hline
\end{tabular}

${ }^{\dagger}$ Estimates from Cohen et al. (2009).

\section{Wreck Island, Virginia}

Dry sand habitat on Wreck Island increased from 32 ha in 2002 to 73.1 ha in 2006 (128\% increase; Table 1; Fig A1.3). Prior to Hurricane Isabel, there had not been plovers nesting on the island since 1997, but plovers recolonized the island in 2004, and reached a maximum of eight pairs in 2007. From 2004-2007, the average population increase per year was $95.8 \%(\mathrm{SE}=37.5 \%)$. Density increased from 0 pairs/ha to 0.08 pairs/ha in 2006. Because of the low number of pairs and logistical challenges, reproductive output was not monitored on Wreck Island during the post-Isabel years. The Wreck Island birds were part of the Virginia population increase described above for Cedar and Metompkin islands.

\section{Missouri River, South Dakota and Nebraska}

High water in 2010 and a 2011 flood on the Missouri River affected both available habitat and nesting plovers. The flood in 2011 encompassed the entire breeding season and left no habitat for nesting birds. There was 119.2 ha of dry sand nesting habitat in 2009 before the events and 1250.9 ha after in $2014(950 \%$ increase). The year before the high water events in 2010, there were 119 nesting pairs in this stretch of the river. Following the flood, the number of nesting pairs decreased initially to 68 pairs in $2012(-57 \%)$ and peaked at 285 pairs in $2016(319 \%$ increase over 2012; Fig. 3). The average annual percent increase from 2013 to 2016 was $43.6 \%$ (SE $=7.2 \%$ ). Pair density decreased from 1 pair/ha to 0.095 pair/ha in 2009 and 2014, respectively (Table 1). Following the events, reproductive output on the Gavins Point Reach was above the reproductive output required for a stationary population needed in every year (Fig. 5). Pair counts on the Missouri River from the Fort Peck Dam in Montana to Gavins Point Reach (approximately $1300 \mathrm{~km}$ ) also increased from 453 pairs in 2009 to 916 pairs in 2016 (102\% increase; U.S. Army Corps of Engineers, unpublished data). Following the 2011 flood, reproductive output for this region of the Missouri River was $1.17-1.49$ chicks/pair.
Fig. 5. Sattelite images of a portion of the Missouri River classification from 2009 (top) and 2014 (bottom). Land-cover classification from eCognition is overlaid on the images. The habitat class "other" includes clouds, shadows, and human development. High water and flooding occurred on the Missouri River in 2010 and 2011.
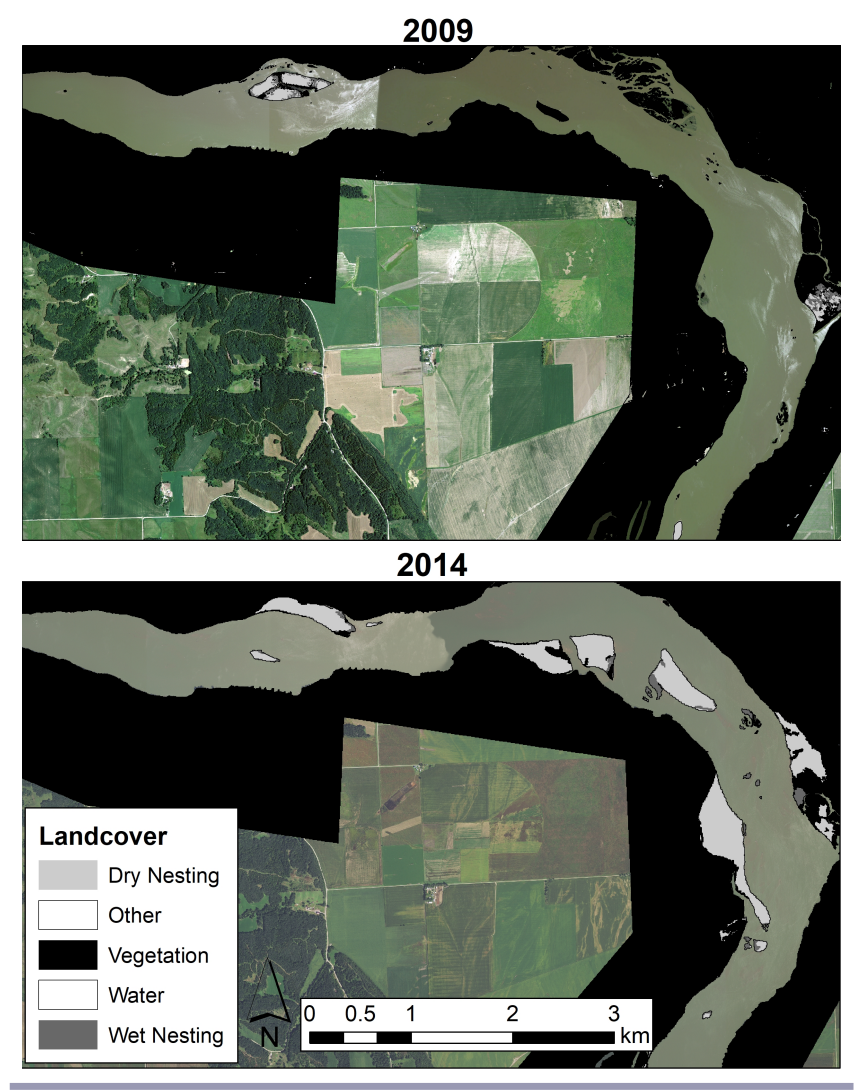
High water events on the Missouri River, documented by higher than average monthly outflow from the Gavins Point Dam in 1996 and 1997, also resulted in a population increase (GAPT Reservoir: http://www.nwd-mr.usace.army.mil/rcc/projdata/gapt.pdf). The population in Gavins Point Reach in 1995 was at a low of 26 pairs before the high water events and reached a high of 143 pairs in 2003 (450\% increase), annually increasing on average $65.5 \%$ (SE $=31.0 \%$ ). These increases were part of a regional increase from 197 pairs in 1995 to 397 pairs in 2000 . Reproductive output for the Missouri River during this time was $1-1.58$ chicks/pair.

\section{Westhampton Island, New York}

We used data from two documented irruptions on Westhampton Island, New York, prior to availability of fine-scale imagery. The first occurred after the hurricane of 1938. In 1937, the plover population within the study area was 9 pairs. By 1941, the population had increased $622 \%$ to 65 pairs, with an average annual increase of $73.9 \%$ (SE $=33.4 \%$; Wilcox 1959).

In the same area, in 1992, a nor'easter created new nesting and foraging habitat on West Hampton Island, leading to an increase from 0 pairs before the storm to a peak of 39 in 2000. Pair density before the storm was 0 pairs/ha. At peak population, the density was 0.90 pairs/ha but increased to 1.05 pairs/ha the following year after a decrease in habitat (Table 1; Cohen et al. 2009). The average increase during the years the population was increasing was $37.1 \%$ ( $\mathrm{SE}=23.6 \%$ ). Reproductive output during this time was variable, with 4 years below and 4 years above that required for a stationary population (Fig. 5). During the same time as the increase that occurred in the 1990s, the entire New York population increased from 191 pairs in 1992 to 289 pairs in 2000 (USFWS 2016). Regional reproductive output for the New York and New Jersey area was close to or above the reproductive output required for a stationary population $(0.97-1.35)$ during this period.

\section{Assateague Island, Maryland}

Nor'easters on Assateague Island in Maryland in the early 1990s were also followed by an irruption of plovers in the area, with Maryland pair counts increasing from 14 to 60 pairs between 1990 and 1997 (329\% increase; Schupp et al. 2013, USFWS 2017), and annually increased on average $48.2 \%(\mathrm{SE}=10.1 \%)$ during the years the population was increasing. Reproductive output on Assateague Island was below the estimated amount required for stationarity prior to the nor'easters. Reproductive output increased above the amount required for stationarity following the nor'easters and remained high for 4 years, although the trend was declining after 2 years (Fig. 4). Following 1997, the beach was modified to reduce further overwash, and the habitat converted to herbaceous vegetation (Schupp et al. 2013). Assateague Island comprises the majority of nesting habitat in Maryland so the increases on Assateague Island contributed $100 \%$ of the increase in Maryland; however, the neighboring states of Delaware and Virginia either remained stationary or declined during this period (USFWS 2016). Regional reproductive output was variable during this time, with some years above and some years below that required for a stationary population $(0.62-1.37)$.

\section{DISCUSSION}

Our findings support our hypothesis that the focal plover populations were at the carrying capacity of their habitats such that when the amount of habitat increased, plover populations increased. Across all sites, when habitat increased, the populations we monitored increased by $72-622 \%$, increasing on average $12-$ $116 \%$ annually. The mechanism behind population growth may have differed among events; local reproductive output was not always at or above the estimated rate required for stationarity, which suggests that immigrating adults and regionally high reproductive output contributed significantly to the population increase in several of the populations we studied. In every case except Wilcox (1959), where information is lacking, the population irruptions were part of regional increases, not just instances of small movements of birds that already existed in these populations.

Some storms overwash barrier island habitats and create bayside foraging habitat and can also increase dry sand habitat (Fig. 2; Leatherman 1979, Maslo et al. 2019, Walker et al. 2019). On the Missouri River, high outflow from the Gavins Point Dam and flooding created new, unvegetated sandbars (USACE 2012), resulting in a population increase (Fig. 3). Similarly, overwash and storm surges on barrier islands between New York and North Carolina throughout the last century created broad areas of open nesting habitat, which were followed by population increases (Fig. 3; Wilcox 1959, Cohen et al. 2009, Schupp et al. 2013). Evidence also suggests that when habitat is not created, populations remain stable or decline. This decline was observed with pair declines on Jones Island, New York, where the population declined following decreases in both nesting and foraging habitats (McIntyre et al. 2010). Similarly, plover populations on Fire Island, New York were declining until Hurricane Sandy created habitat in the fall of 2012 (Walker et al. 2019).

The density (pairs/ha) of birds from all of our Atlantic Coast study areas increased following Hurricane Isabel. Cohen et al. (2009) estimated the carrying capacity of Westhampton Island to be $0.44-1.05$ pairs/ha, with greater densities detected in areas where flightless plover chicks could access both ocean and bayside foraging habitats. Our estimated densities were lower than the later Westhampton Island study in all other cases; however, most populations were still growing in the years for which we have habitat estimates. We would need additional estimates of habitat when the populations reached carrying capacity to be directly comparable with past studies. The carrying capacity of plovers may be lower at lower latitudes (USFWS 1996, Hecht and Melvin $2009 b$ ), which would be consistent with our lower densities in Virginia and North Carolina than in more northerly populations. However, density likely initially decreased in all cases in the year following the storm because of more habitat and fewer pairs than when we classified imagery.

The Missouri River plover population in 2010-2016 is the only case where postevent density was lower than preevent densities at the time of classification following the events. The amount of habitat created by the floods was much greater than that of the Atlantic Coast cases, and even the extremely high productivity could not have produced enough birds to occupy all of the available habitat during the study. On the Missouri River, population increases were driven by increased productivity from reduced density-dependent predation on nests and chicks and competition (Hunt et al. 2018) and, to a lesser extent, by immigration (Catlin et al. 2015, 2016). There was an initial 
detrimental effect from both the high water events in the 1990s and the high water and flooding in the 2000s. Reduced survival and low reproductive output during the flood also could have contributed to the low postevent densities. The flood in 2011 both reduced adult survival (Weithman et al. 2017, Hunt et al. 2018) and produced few recruits to colonize the newly created habitat (Hunt et al. 2018), leading to an initial population decline and a lag in the population increase. Despite the initial lag, the plover population responded with record high reproductive output and exhibited nearly exponential growth for several years before stabilizing (Hunt et al. 2018, 2019).

The mechanisms behind the density-dependent population growth at the Atlantic Coast sites are unclear. In all cases except Maryland, the population immediately increased. To balance the natural mortality of these populations, an estimated annual productivity of approximately 1.2 chicks/pair is required (Melvin and Gibbs 1996). The immediate population increases following storm events could have been caused by a reduction in densitydependent competition. An increase in nesting habitat could have allowed space for first-time breeders to find territories following regional productivity above that required for a stationary population in the year prior to the storm or space for birds that had not bred before because of a lack of available territories (Fig. 4; Newton 1998). The increase in habitat could also have allowed chicks greater access to quality foraging habitats, increasing chick survival and recruitment. However, the required number of chicks for stationarity was not produced in all years at all sites following the focal hurricanes and nor'easters, despite consistently increasing populations. Thus, immigration likely played a larger role in the Atlantic Coast irruptions than in the Great Plains irruptions, especially for the southern U.S. sites, where regional reproductive output was high (1.63 chicks/pair) in the breeding season prior to Hurricane Isabel (Fig. 4; USFWS 2016). The difference in apparent contribution from immigration between the Great Plains and the Atlantic Coast also may be a function of the spatial scale of our investigation because an area's apparent immigration rate is affected by its size. In large study areas, individuals settling may be regarded as natal recruits, whereas in a tiny area, most will be classed as immigrants (Newton 1998). The Gavins Point Reach of the Missouri River is 10 times the size of any of the other study sites. Therefore, small local movements such as an adult moving to different nesting sandbars between years would not be considered immigration or emigration.

A study in eastern Canada, near the northern end of the Piping Plover's Atlantic Coast range, found that the number of fledglings increased following winter storms similar to Hurricane Isabel and the nor'easters reported here (Bourque et al. 2015). However, Bourque et al. (2015) did not find a strong relationship with pair counts, suggesting that the amount of habitat created following storms was too little to change the amount of available nesting habitat significantly given the current population, but did allow for more foraging habitat for prefledged chicks. Alternatively, other factors could be affecting this population's growth rate such as factors outside of the breeding season.

The effects of several of the events observed in our study also were seen at broader scales. Westhampton Island only contributed $40 \%$ of the regional increase in New York, and regional reproductive output likely also contributed birds to the local increase in some years. The overall pair increase we documented on Cedar, Wreck, and Metompkin islands accounted for $79 \%$ of the Virginia population increase, and only $55 \%$ of the pair increase in North Carolina came from the focal area on Ophelia Inlet. Regional reproductive output was high and thus also likely supplied birds to settle into the newly created habitats at both the Virginia and North Carolina sites following Hurricane Isabel, further suggesting that birds were not just moving around within the region. The irruption on the Missouri River in the 1990s only contributed $23 \%$ to the regional increase, and similarly, in the 2000s, only $36 \%$ was from the Gavins Point Reach (U.S. Army Corps of Engineers, unpublished data); in general, regional reproductive output was high following both events. That the irruptions were evident at both fine and broad scales provides evidence that the increases were widespread, likely from habitat also being created at nearby sites other than the ones we focused on here, rather than adults shifting small distances to occupy the new habitats and leaving their original territory unoccupied.

Additional benefits of an increase in habitat could be a reduction in density-dependent competition for other disturbancedependent shore species such as American Oystercatcher, Least Tern (Sternula antillarum), Killdeer (Charadrius vociferus), and Wilson's Plover (Charadrius wilsonia; Elliott-Smith and Haig 2004). On Atlantic Coast barrier islands, American Oystercatcher nests in similar habitat as plovers, has been known to have aggressive encounters with plovers, and is suspected to have caused plover nest failure in some cases (Hogan et al. 2018; S. Robinson, personal observation). Similarly, aggression between Wilson's Plover and Piping Plover is suspected to influence territory spacing in Virginia (Bergstrom and Terwilliger 1987). A reduction in interspecific competition by an increase in habitat may have allowed an increase in areas for plovers to settle in some cases, contributing to positive population growth for Piping Plover.

Evidence of the effect of habitat change on populations of breeding plovers is commonly studied at individual breeding sites (Boettcher et al. 2007, Cohen et al. 2009, Schupp et al. 2013, Catlin et al. 2015). Plovers on the Atlantic coast are dependent on overwash from high water levels to control vegetation (Cohen et al. 2009). Plovers in riverine systems are dependent on floods occurring at relatively frequent intervals to create habitat and reduce vegetation encroachment (Zeigler et al. 2017, Hunt et al. 2018). In many of these disturbance-dependent systems, human intervention can act as a surrogate for the natural systems by building habitat that allows the population to increase (Catlin et al. 2015). However, it may be necessary to intervene in a manner that would mimic prior disturbance regimes to avoid detrimental effects that may result from static habitat such as climax vegetation. Human intervention can also increase functional habitat for plovers and other beach-nesting shorebirds by protecting habitat from human use. Typically, this is in the form of restricted pedestrian and vehicle access. Population increases following functional habitat increase are also suggestive of habitat limitation, with an increase in habitat and a decrease in functional density resulting from protection rather than creation. An example of this for plovers is in Massachusetts, where the population has increased nearly $400 \%$ from 136 to 687 pairs since listing, primarily because of active human and habitat management (USFWS 2016). 
Human intervention has increased available habitat and led to population increases with Little Ringed Plover (Charadrius dubius), Long-billed Plover (Charadrius placidus), and Piping Plover (Parrinder 1989, Cohen et al. 2009, Katayama et al. 2010, Arlettaz et al. 2011, Catlin et al. 2015, Walker et al. 2019). On the Missouri and other prairie rivers, Westhampton Island, and Assateague Island, human actions mainly acted to inhibit the natural dynamics by building dams and channelizing the river (Cohen et al. 2009, Schupp et al. 2013, Catlin et al. 2015). The Virginia barrier islands and Cape Lookout are not managed to prevent or repair overwash, unlike many other barrier islands, which is likely why the habitat from Hurricane Isabel was created and persisted. Thus, although human intervention can create habitat for short-term plover increases, natural dynamics or repeated human interventions are essential for habitat maintenance.

It is important to understand what is limiting populations of imperiled species to manage properly for population recovery. A population that is regulated by density-dependent factors also can be decreased, at least temporarily, by density-independent factors such as storms or overharvest. Density-dependent vital rates such as reproduction, immigration, and emigration, and factors affecting those rates, such as predation, can be influenced by the amount of available habitat, and their effect on a population can increase or decrease with a change in the amount of habitat. However, if the effect of habitat limitation is not acknowledged when trying to influence such factors, ineffective management can occur. Predation has been shown influence plover success (e.g., Patterson et al. 1991, Catlin et al. 2011a, Hunt et al. 2018), and predation rates can vary with habitat such that an increase in habitat can influence nest and chick survival by reducing detection by predators (Elliott-Smith and Haig 2004, Catlin et al. 2015, Swaisgood et al. 2017, Hunt et al. 2018). Predator populations also can be reduced by events that create habitat for piping plovers, such as hurricanes and floods, but a single reduction event may not affect prey populations for long (Stocking et al. 2017). Therefore, if predators are managed where prey are habitatlimited and the amount of habitat does not increase, the population response may be small and inconsistent. It can be challenging to identify the proximate causes of population change; thus, additional studies of habitat, prey populations, predator populations, and their interactions would be beneficial.

Although the Piping Plover has experienced range-wide population increases since its listing in 1986, it has not reached recovery goals in most areas (USFWS 2009, 2016). With strong evidence for habitat limitation across the plover's range, creating and enhancing habitat that is also managed to avoid human disturbance and predator subsidization should allow populations to grow. For Atlantic Coast plovers, allowing overwash to occur naturally will help to restore and maintain their early successional habitat (Schupp et al. 2013). Natural overwash should be allowed, where possible, in plover nesting areas, for the benefit of both plovers and the barrier island because natural inlet formation and overwash processes assist in maintaining barrier islands (Smith et al. 2008, Seavey et al. 2011). It also is possible that increased storminess from climate change (Weisse et al. 2012, Vermaire et al. 2013) could enhance plover nesting habitat on the Atlantic Coast by increasing the frequency of overwash and breaches, unless the islands are altered to prevent such habitat change.
Barrier islands that have been engineered to prevent overwash will likely require frequent active management to mimic the disturbance of a habitat-creating event (Elias et al. 2000, Cohen et al. 2009). For Missouri River plovers, floods such as the one that occurred in 2011 are damaging and expensive to the human infrastructure near the river (USACE 2012). Building habitat to mimic the flood-created sandbars can mitigate the successional transition of the sandbars from open sand to highly vegetated, although building rarely mimics the scale of natural creation because of the expense (Hunt et al. 2018). However, habitat creation can be successful for both river and coastal plovers (Cohen et al 2009, Hunt et al. 2018). Future management for plovers range-wide should focus on increasing the amount of available habitat and restoring natural habitat disturbance regimes where possible, therefore increasing the overall carrying capacity of the plover range and allowing populations to reach regional and range-wide recovery goals.

Responses to this article can be read online at: http://www.ace-eco.org/issues/responses.php/1373

\section{Acknowledgments:}

We thank all of the volunteers, interns, and technicians from several agencies who collected data over the years. We thank E. L. Heller and $H$. A. Bellman for assistance with classifying imagery. We also thank Anne Hecht and two anonymous reviewers for their comments on earlier drafts of this manuscript. Part of the work conducted here is supported by the National Science Foundation Virginia Coast Reserve Long Term Ecological Research Grant DEB-1237733. Any opinions, findings, and conclusions or recommendations expressed in this material are those of the authors and do not necessarily reflect the views of the National Science Foundation, U.S. Fish and Wildlife Service, Virginia Department of Games and Inland Fisheries, The Nature Conservancy, National Park Service, or U.S. Army Corps of Engineers. The contents of this report are not to be used for advertising, publication, or promotional purposes. Reference to trade names does not imply endorsement by the U.S. Government. All product names and trademarks cited are the property of their respective owners. The findings of this report are not to be construed as an official Department of Army position unless so designated by other authorized documents.

\section{LITERATURE CITED}

Arlettaz, R., A. Lugon, A. Sierro, P. Werner, M. Kéry, and P. A. Oggier. 2011. River bed restoration boosts habitat mosaics and the demography of two rare non-aquatic vertebrates. Biological Conservation 144(8):2126-2132. https://doi.org/10.1016/j.

biocon.2011.05.003

Baudains, T. P., and P. Lloyd. 2007. Habituation and habitat changes can moderate the impacts of human disturbance on shorebird breeding performance. Animal Conservation 10 (3):400-407. https://doi.org/10.1111/j.1469-1795.2007.00126.x

Bergstrom, P. W., and K. Terwilliger. 1987. Nest sites and aggressive behaviour of piping and Wilson's plovers in Virginia: some preliminary results. Wader Study Group Bulletin 50:35-39. 
[online] URL: https://sora.unm.edu/sites/default/files/journals/ iwsgb/n050/p00035-p00039.pdf

Boettcher, R., T. Penn, R. R. Cross, K. T. Terwilliger, and R. A. Beck. 2007. An overview of the status and distribution of piping plovers in Virginia. Waterbirds 30(SP1):138-151. [online] URL: https://www.jstor.org/stable/25148282

Bourque, N. R., M.-A. Villard, M. J. Mazerolle, D. AmiraultLanglais, E. Tremblay, and S. Jolicoeur. 2015. Piping Plover response to coastal storms occurring during the nonbreeding season. Avian Conservation and Ecology 10:12. http://dx.doi. org/10.5751/ACE-00734-100112

Brook, B. W., and C. J. A. Bradshaw. 2006. Strength of evidence for density dependence in abundance time series of 1198 species. Ecology 87(6):1445-1451. https://doi.org/10.1890/0012-9658 (2006)87[1445:SOEFDD]2.0.CO;2

Buehler, D. A. 2000. Bald Eagle (Haliaeetus leucocephalus), version 2.0. In A. F. Poole and F. B. Gill, editors. The birds of North America. Cornell Lab of Ornithology, Ithaca, New York, USA. https://doi.org/10.2173/bna.506

Burger, J. 1987. Physical and social determinants of nest-site selection in Piping Plover in New Jersey. Condor 89(4):811-818. https://doi.org/10.2307/1368529

Cairns, W. E. 1982. Biology and behavior of breeding piping plovers. Wilson Bulletin 94(4):531-545. [online] URL: https://sora. unm.edu/sites/default/files/journals/wilson/v094n04/p0531-p0545. pdf

Catlin, D. H., J. H. Felio, and J. D. Fraser. 2011a. Effect of greathorned owl trapping on chick survival in piping plovers. Journal of Wildlife Management 75(2):458-462. https://doi.org/10.1002/ jwmg.56

Catlin, D. H., J. D. Fraser, and J. H. Felio. 2015. Demographic responses of piping plovers to habitat creation on the Missouri River. Wildlife Monographs 192:1-42. https://doi.org/10.1002/ wmon.1016

Catlin, D. H., J. D. Fraser, J. H. Felio, and J. B. Cohen. $2011 b$. Piping Plover habitat selection and nest success on natural, managed, and engineered sandbars. Journal of Wildlife Management 75(2):305-310. https://doi.org/10.1002/jwmg.46

Catlin, D. H., S. L. Zeigler, M. B. Brown, L. R. Dinan, J. D. Fraser, K. L. Hunt, and J. G. Jorgensen. 2016. Metapopulation viability of an endangered shorebird depends on dispersal and humancreated habitats: piping plovers (Charadrius melodus) and prairie rivers. Movement Ecology 4:6. https://doi.org/10.1186/s40462-016-0072y

Chan, H. K., K. T. Shoemaker, and N. E. Karraker. 2014. Demography of Quasipaa frogs in China reveals high vulnerability to widespread harvest pressure. Biological Conservation 170:3-9. https://doi.org/10.1016/j.biocon.2013.12.014

Cohen, J. B., L. M. Houghton, and J. D. Fraser. 2009. Nesting density and reproductive success of piping plovers in response to storm- and human-created habitat changes. Wildlife Monographs 173:1-24. https://doi.org/10.2193/2007-553
Cohen, J. B., J. D. Fraser, and D. H. Catlin. 2006. Survival and site fidelity of piping plovers on Long Island, New York. Journal of Field Ornithology 77(4):409-417. https://doi.org/10.1111/ j.1557-9263.2006.00072.x

Cooch, E. G., D. B. Lank, R. F. Rockwell, and F. Cooke. 1989. Long-term decline in fecundity in a Snow Goose population: evidence for density dependence? Journal of Animal Ecology 58 (2):711-726. https://doi.org/10.2307/4858

Cooper, S. 1990. Notes on piping plovers nesting at Cape Hatteras National Seashore during 1987. Chat 54:1-6.

Dolman, P. M., and W. J. Sutherland. 1995. The response of bird populations to habitat loss. Ibis 137(s1):S38-S46. https://doi. org/10.1111/j.1474-919X.1995.tb08456.X

Elias, S. P., J. D. Fraser, and P. A. Buckley. 2000. Piping plover brood foraging ecology on New York barrier islands. Journal of Wildlife Management 64(2):346-354. https://doi.org/10.2307/3803232

Elliott-Smith, E., and S. M. Haig. 2004. Piping Plover (Charadrius melodus). In A. Poole, editor. The birds of North America. Cornell Lab of Ornithology, Ithaca, New York, USA. [online] URL: https://doi.org/10.2173/bna.2

Flockhart, D. T. T., J. B. Pichancourt, D. R. Norris, and T. G. Martin. 2015. Unravelling the annual cycle in a migratory animal: breeding-season habitat loss drives population declines of monarch butterflies. Journal of Animal Ecology 84(1):155-165. https://doi.org/10.1111/1365-2656.12253

Francis, C. M., M. H. Richards, F. Cooke, and R. F. Rockwell. 1992. Long-term changes in survival rates of lesser snow geese. Ecology 73(4):1346-1362. https://doi.org/10.2307/1940681

Fraser, J. D., S. E. Keane, and P. A. Buckley. 2005. Prenesting use of intertidal habitats by piping plovers on South Monomoy Island, Massachusetts. Journal of Wildlife Management 69 (4):1731-1736. https://doi.org/10.2193/0022-541X(2005)69[1731: PUOIHB]2.0.CO;2

Gieder, K. D., S. M. Karpanty, J. D. Fraser, D. H. Catlin, B. T. Gutierrez, N. G. Plant, A. M. Turecek, and E. R. Thieler. 2014. A Bayesian network approach to predicting nest presence of the federally-threatened piping plover (Charadrius melodus) using barrier island features. Ecological Modelling 276:38-50. https:// doi.org/10.1016/j.ecolmodel.2014.01.005

Grier, J. W. 1982. Ban of DDT and subsequent recovery of reproduction in bald eagles. Science 218(4578):1232-1235. https:// doi.org/10.1126/science.7146905

Hamilton, R. J., T. Bird, C. Gereniu, J. Pita, P. C. Ramohia, R. Walter, C. Goerlich, and C. Limpus. 2015. Solomon Islands largest hawksbill turtle rookery shows signs of recovery after 150 years of excessive exploitation. Plos One 10(4):e0121435. https:// doi.org/10.1371/journal.pone.0121435

Hecht, A., and S. M. Melvin. 2009a. Expenditures and effort associated with recovery of breeding Atlantic coast piping plovers. Journal of Wildlife Management 73(7):1099-1107. https:// doi.org/10.2193/2008-061

Hecht, A., and S. M. Melvin. 2009b. Population trends of Atlantic coast piping plovers, 1986-2006. Waterbirds 32(1):64-72. https:// doi.org/10.1675/063.032.0107 
Hillman, M. D., S. M. Karpanty, J. D. Fraser, F. J. Cuthbert, J. M. Altman, and T. E. Borneman. 2012. Evidence for longdistance dispersal and successful interpopulation breeding of the endangered Piping Plover. Waterbirds 35(4):642-644. https://doi. org/10.1675/063.035.0414

Hixon, M., S. Pacala, and S. Sandin. 2002. Population regulation: historical context and contemporary challenges of open vs. closed systems. Ecology 83(6):1490-1508. https://doi.org/10.1890/0012-9658 (2002)083[1490:PRHCAC]2.0.CO;2

Hogan, B. R., M. M. Grigione, M. A. Marconi, R. E. Thomas, and R. J. Sarno. 2018. Asymmetric antagonism between piping plovers (Charadrius melodus) and American oystercatchers (Haematopus palliatus), New York, USA. Waterbirds 41 (4):443-448. https://doi.org/10.1675/063.041.0414

Hunt, K. L., J. D. Fraser, M. J. Friedrich, S. M. Karpanty, and D. H. Catlin. 2018. Demographic response of an imperiled bird suggests that engineered habitat restoration is no match for natural riverine processes. Condor 120(1):149-165. https://doi. org/10.1650/CONDOR-17-93.1

Hunt, K. L., J. D. Fraser, S. M. Karpanty, and H. Daniel. 2017. Body condition of piping plovers (Charadrius melodus) and prey abundance on flood-created habitat on the Missouri River, USA. Wilson Journal of Ornithology 129(4):754-764. https://doi. org/10.1676/16-180.1

Hunt, K. L., D. Gibson, M. J. Friedrich, C. J. Huber, J. D. Fraser, S. M. Karpanty, and D. H. Catlin. 2019. Using nest captures and video cameras to estimate survival and abundance of breeding piping plovers Charadrius melodus. Ibis, in press. https://doi. org/10.1111/ibi.12726

Katayama, N., T. Amano, and S. Ohori. 2010. The effects of gravel bar construction on breeding long-billed plovers. Waterbirds 33 (2):162-168. https://doi.org/10.1675/063.033.0204

Kokko, H., and W. J. Sutherland. 2001. Ecological traps in changing environments: ecological and evolutionary consequences of a behaviourally mediated Allee effect. Evolutionary Ecology Research 3(5):603-610. [online] URL: http://evolutionaryecology.com/abstracts/v03n05/eear1308.pdf

Kwon, E., J. D. Fraser, D. H. Catlin, S. M. Karpanty, C. E. Weithman, and B. Muiznieks. 2018. Presence of ghost crabs and piping plover nesting success. Journal of Wildlife Management 82 (4):850-856. https://doi.org/10.1002/jwmg.21422

Le Fer, D., J. D. Fraser, and C. D. Kruse. 2008. Piping Plover foraging-site selection on the Missouri River. Waterbirds 31 (4):587-592. https://doi.org/10.1675/1524-4695-31.4.587

Leatherman, S. P. 1979. Migration of Assateague Island, Maryland, by inlet and overwash processes. Geology 7(2):104-107. https://doi.org/10.1130/0091-7613(1979)7<104:MOAIMB>2.0.CO;2

Licht, D. S., R. A. Moen, D. P. Brown, M. C. Romanski, and R. A. Gitzen. 2015. The Canada Lynx (Lynx canadensis) of Isle Royale: over-harvest, climate change, and the extirpation of an island population. Canadian Field-Naturalist 129(2):139-151. https://doi.org/10.22621/cfn.v129i2.1694

Loegering, J. P., and J. D. Fraser. 1995. Factors affecting Piping Plover chick survival in different brood-rearing habitats. Journal of Wildlife Management 59(4):646-655. https://doi.org/10.2307/3801940
Marra, P. P., C. E. Studds, S. Wilson, T. S. Sillett, T. W. Sherry, R. T. Holmes. 2015. Non-breeding season habitat quality mediates the strength of density-dependence for a migratory bird Proceedings of the Royal Society B 282:201550624. https://doi. org/10.1098/rspb.2015.0624

Martin, T. E. 2015. Consequences of habitat change and resource selection specialization for population limitation in cavity-nesting birds. Journal of Applied Ecology 52(2):475-485. https://doi. org/10.1111/1365-2664.12375

Maslo, B., K. Leu, T. Pover, M. A. Weston, B. L. Gilby, and T. A. Schlacher. 2019. Optimizing conservation benefits for threatened beach fauna following severe natural disturbances. Science of the Total Environment 649:661-671. https://doi.org/10.1016/j. scitotenv.2018.08.319

McIntyre, A. F., J. A. Heath, and J. Jannsen. 2010. Trends in Piping Plover reproduction at Jones Beach State Park, NY, 1995-2007. Northeastern Naturalist 17(3):493-504. https://doi. org/10.1656/045.017.0309

Melvin, S. M., and J. P. Gibbs. 1996. Viability analysis for the Atlantic coast population of piping plovers. Pages 175-186 in Piping Plover (Charadrius melodus), Atlantic coast population, revised recovery plan. U.S. Fish and Wildlife Service, Haldey, Massachusetts, USA.

Nadjafzadeh, M., H. Hofer, and O. Krone. 2013. The link between feeding ecology and lead poisoning in white-tailed eagles. Journal of Wildlife Management 77(1):48-57. https://doi.org/10.1002/ jwmg.440

Newton, I. 1998. Population limitation in birds. Academic Press, New York, New York, USA.

Nicholson, A. J. 1933. Supplement: the balance of animal populations. Journal of Animal Ecology 2(1):131-178. https://doi. org/10.2307/954

Norris, D. R., P. P. Marra, T. K. Kyser, T. W. Sherry, and L. M. Ratcliffe. 2004. Tropical winter habitat limits reproductive success on the temperate breeding grounds in a migratory bird. Proceedings of the Royal Society B 271(1534):59-64. https://doi. org/10.1098/rspb.2003.2569

Parrinder, E. D. 1989. Little ringed plovers Charadrius dubius in Britain in 1984. Bird Study 36(3):147-153. https://doi. org/10.1080/00063658909477019

Patterson, M. E., J. D. Fraser, and J. W. Roggenbuck. 1990. Piping Plover ecology, management, and research needs. Virginia Journal of Science 41(4A):419-426.

Patterson, M. E., J. D. Fraser, and J. W. Roggenbuck. 1991. Factors affecting Piping Plover productivity on Assateague Island. Journal of Wildlife Management 55(3):525-531. https:// doi.org/10.2307/3808985

Pulliam, H. R. 1988. Sources, sinks, and population regulation. American Naturalist 132(5):652-661. https://doi.org/10.1086/284880

Putman, R. J., J. Langbein, A. J. M. Hewison, and S. K. Sharma. 1996. Relative roles of density-dependent and densityindependent factors in population dynamics of British deer. Mammal Review 26:81-101. https://doi.org/10.1111/j.1365-2907.1996. tb00148.x 
Radoux, J., P. Bogaert, D. Fasbender, and P. Defourny. 2011. Thematic accuracy assessment of geographic object-based image classification. International Journal of Geographical Information Science 25(6):895-911. https://doi.org/10.1080/13658816.2010.498378

Schulte, S. A., and T. R. Simons. 2016. Hurricane disturbance benefits nesting American oystercatchers (Haematopus palliatus). Waterbirds 39:327-337. https://doi.org/10.1675/063.039.0402

Schupp, C. A., N. T. Winn, T. L. Pearl, J. P. Kumer, T. J. B. Carruthers, and C. S. Zimmerman. 2013. Restoration of overwash processes creates piping plover (Charadrius melodus) habitat on a barrier island (Assateague Island, Maryland). Estuarine, Coastal and Shelf Science 116:11-20. https://doi.org/10.1016/j.ecss.2012.07.003

Seavey, J. R., B. Gilmer, and K. M. McGarigal. 2011. Effect of sea-level rise on piping plover (Charadrius melodus) breeding habitat. Biological Conservation 144(1):393-401. https://doi. org/10.1016/j.biocon.2010.09.017

Sheng, Y. P., V. Alymov, and V. A. Paramygin. 2010. Simulation of storm surge, wave, currents, and inundation in the Outer Banks and Chesapeake Bay during Hurricane Isabel in 2003: the importance of waves. Journal of Geophysical Research: Oceans 115:C04008. https://doi.org/10.1029/2009JC005402

Shields, M. 2014. Brown Pelican (Pelecanus occidentalis), version 2.0. In A. F. Poole and F. B. Gill, editors. The birds of North America. Cornell Lab of Ornithology, Ithaca, New York, USA. [online] URL: https://birdsna.org/Species-Account/bna/species/ brnpel/introduction

Smith, C. G., S. J. Culver, S. R. Riggs, D. Ames, D. R. Corbett, and D. Mallinson. 2008. Geospatial analysis of barrier island width of two segments of the Outer Banks, North Carolina, USA: anthropogenic curtailment of natural self-sustaining processes. Journal of Coastal Research 24(1):70-83. https://doi.org/10.2112/05-0595.1

Stocking, J. J., T. R. Simons, A. W. Parsons, and A. F. O’Connell. 2017. Managing native predators: evidence from a partial removal of raccoons (Procyon lotor) on the Outer Banks of North Carolina, USA. Waterbirds 40(sp1):10-18. https://doi.org/10.1675/063.040. sp103

Strong, L. L. 2012. Extending a prototype knowledge and objectbased image analysis model to coarser spatial resolution imagery: an example from the Missouri River. Proceedings GEOBIA 2012:530-535.

Swaisgood, R. R., L. A. Nordstrom, J. G. Schuetz, J. T. Boylan, J. J. Fournier, and B. Shemai. 2017. A management experiment evaluating nest-site selection by beach-nesting birds. Journal of Wildlife Management 82(1):192-201. https://doi.org/10.1002/ jwmg.21342

Turchin, P. 1990. Rarity of density dependence or population regulation with lags? Nature 344:660-663.

U.S. Army Corps of Engineers (USACE). 2012. Post 2011 flood event analysis of Missouri River mainstem flood control stage. Missouri River Mainstem Reservoir System Report. U.S. Army Corps of Engineers, Northwestern Division, Missouri River Basin Water Management Division, Omaha, Nebraska, USA. [online] URL: http://www.nwd-mr.usace.army.mil/rcc/reports/ pdfs/Post2011FloodEventAnalysisofMainstemFloodControlStorage. pdf
U.S. Department of Agriculture. 2016. NAIP coverage 2002-2016. U.S. Department of Agriculture, Farm Service Agency, Aerial Photography Field Office, Customer Service Section, Salt Lake City, Utah, USA. [online] URL: https://www.fsa.usda.gov/ Assets/USDA-FSA-Public/usdafiles/APFO/status-maps/pdfs/ naipcov_2016.pdf

U.S. Fish and Wildlife Service (USFWS). 1985. Determination of threatened and endangered status for the Piping Plover. U.S. Fish and Wildlife Service, Washington, D.C., USA.

U.S. Fish and Wildlife Service (USFWS). 1996. Piping Plover (Charadrius melodus) Atlantic coast population revised recovery plan. U.S. Fish and Wildlife Service, Hadley, Massachusetts, USA.

U.S. Fish and Wildlife Service (USFWS). 2009. Piping Plover (Charadrius melodus) 5-year review: summary and evaluation. $\mathrm{U}$. S. Fish and Wildlife Service, Hadley, Massachusetts and Lansing, Michigan, USA.

U.S. Fish and Wildlife Service (USFWS). 2016. Draft revised recovery plan for the Northern Great Plains Piping Plover (Charadrius melodus). First revision. U.S. Fish and Wildlife Service, Denver, Colorado, USA. [online] URL: https://www.fws. gov/mountain-prairie/es/species/birds/pipingplover/2016/Vol $\% 20 I \%$ 20NGP $\% 20$ Draft $\% 20$ Revised $\% 20$ Breeding $\% 20$ Rec $\% 20$ Plan.pdf

U.S. Fish and Wildlife Service (USFWS). 2017. Abundance and productivity estimates - 2016 update: Atlantic coast Piping Plover population. U.S. Fish and Wildlife Service, Hadley, Massachusetts, USA. [online] URL: https://www.fws.gov/ northeast/pipingplover/pdf/Abundance_Productivity_2016_Update_final. pdf

Vermaire, J. C., M. F. J. Pisaric, J. R. Thienpont, C. J. Courtney Mustaphi, S. V. Kokelj, and J. P. Smol. 2013. Arctic climate warming and sea ice declines lead to increased storm surge activity. Geophysical Research Letters 40(7):1386-1390. https:// doi.org/10.1002/grl.50191

Walker, K. M., J. D. Fraser, D. H. Catlin, S. J. Ritter, S. G. Robinson, H. A. Bellman, A. L. Derose-Wilson, S. M. Karpanty, and S. T. Papa. 2019. Hurricane Sandy and engineered human response created habitat for a threatened species. Ecosphere, in press. https://doi.org/10.1002/ecs2.2771

Weisse, R., H. von Storch, H. D. Niemeyer, and H. Knaack. 2012. Changing North Sea storm surge climate: an increasing hazard? Ocean and Coastal Management 68:58-68. https://doi. org/10.1016/j.ocecoaman.2011.09.005

Weithman, C., D. Gibson, K. Hunt, M. Friedrich, J. D. Fraser, S. M. Karpanty, and D. H. Catlin. 2017. Senescence and carryover effects of reproductive performance influence migration, condition, and breeding propensity in a small shorebird. Ecology and Evolution 7(24):11044-11056. https://doi.org/10.1002/ ece 3.3533

White, C. M., N. J. Club, T. J. Cade, and W. G. Hunt. 2002. Peregrine Falcon (Falco peregrinus), version 2.0. In A. F. Poole and F. B. Gill, editors. The birds of North America. Cornell Lab of Ornithology, Ithaca, New York, USA. [online] URL: https:// birdsna.org/Species-Account/bna/species/brnpel/introduction 
Wilcox, L. 1959. A twenty year banding study of the Piping Plover. Auk 76(2):129-152. https://doi.org/10.2307/4081772

Wittemyer, G., J. M. Northrup, J. Blanc, I. Douglas-Hamilton, P. Omondi, and K. P. Burnham. 2014. Illegal killing for ivory drives global decline in African elephants. Proceedings of the National Academy of Sciences 111(36):13117-13121. https://doi.org/10.1073/ pnas. 1403984111

Zeigler, S. L., D. H. Catlin, M. Bomberger Brown, J. D. Fraser, L. R. Dinan, K. L. Hunt, J. G. Jorgensen, and S. M. Karpanty. 2017. Effects of climate change and anthropogenic modification on a disturbance-dependent species in a large riverine system. Ecosphere 8(1):e01653. https://doi.org/10.1002/ecs2.1653 
Appendix 1: Additional classification maps

2002

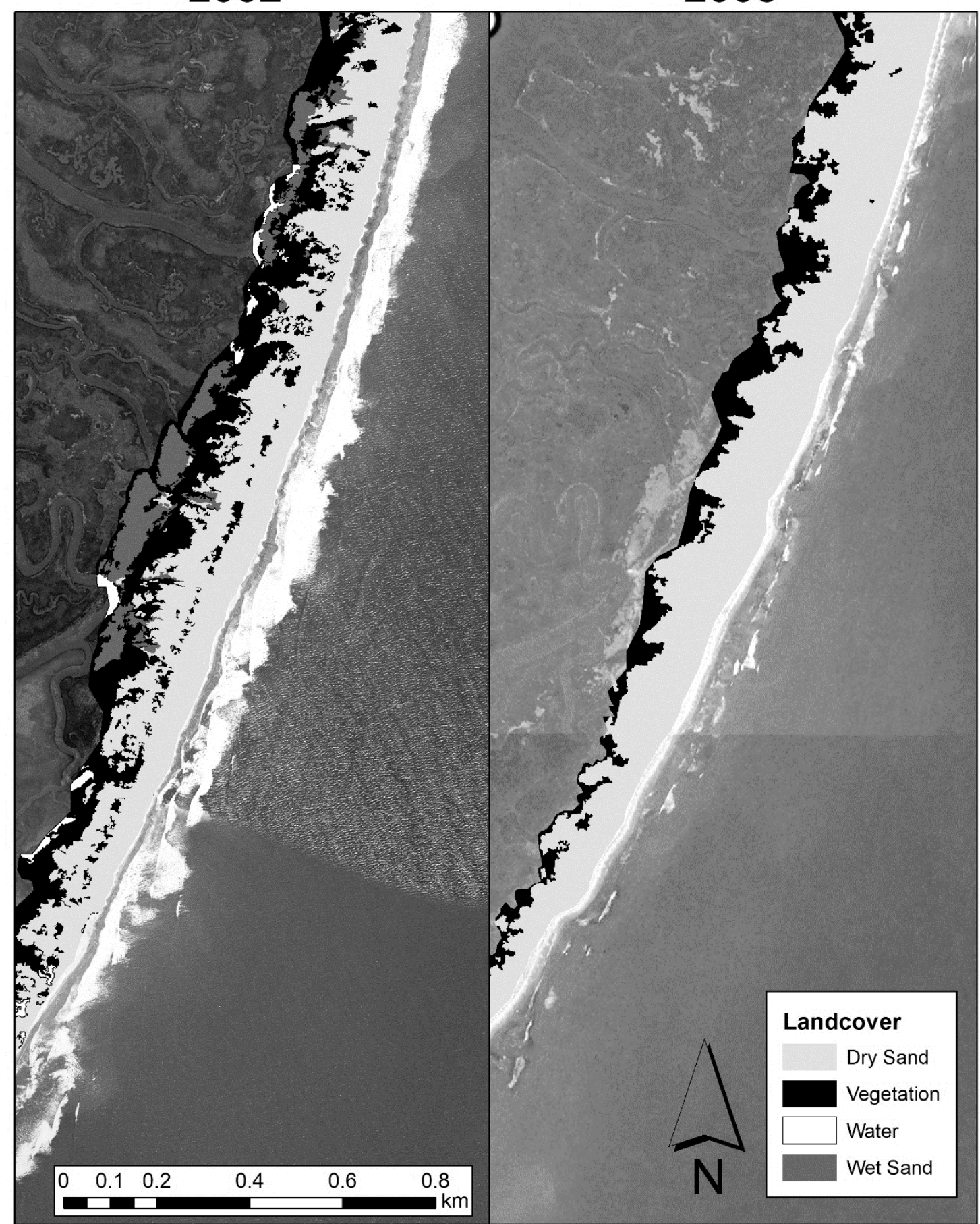

Figure A1.1 Portion of Cedar Island classification from 2002 (left) and 2005 (right). Classification from eCognition overlaid on respective imagery. Hurricane Isabel occurred in the fall of 2003. 


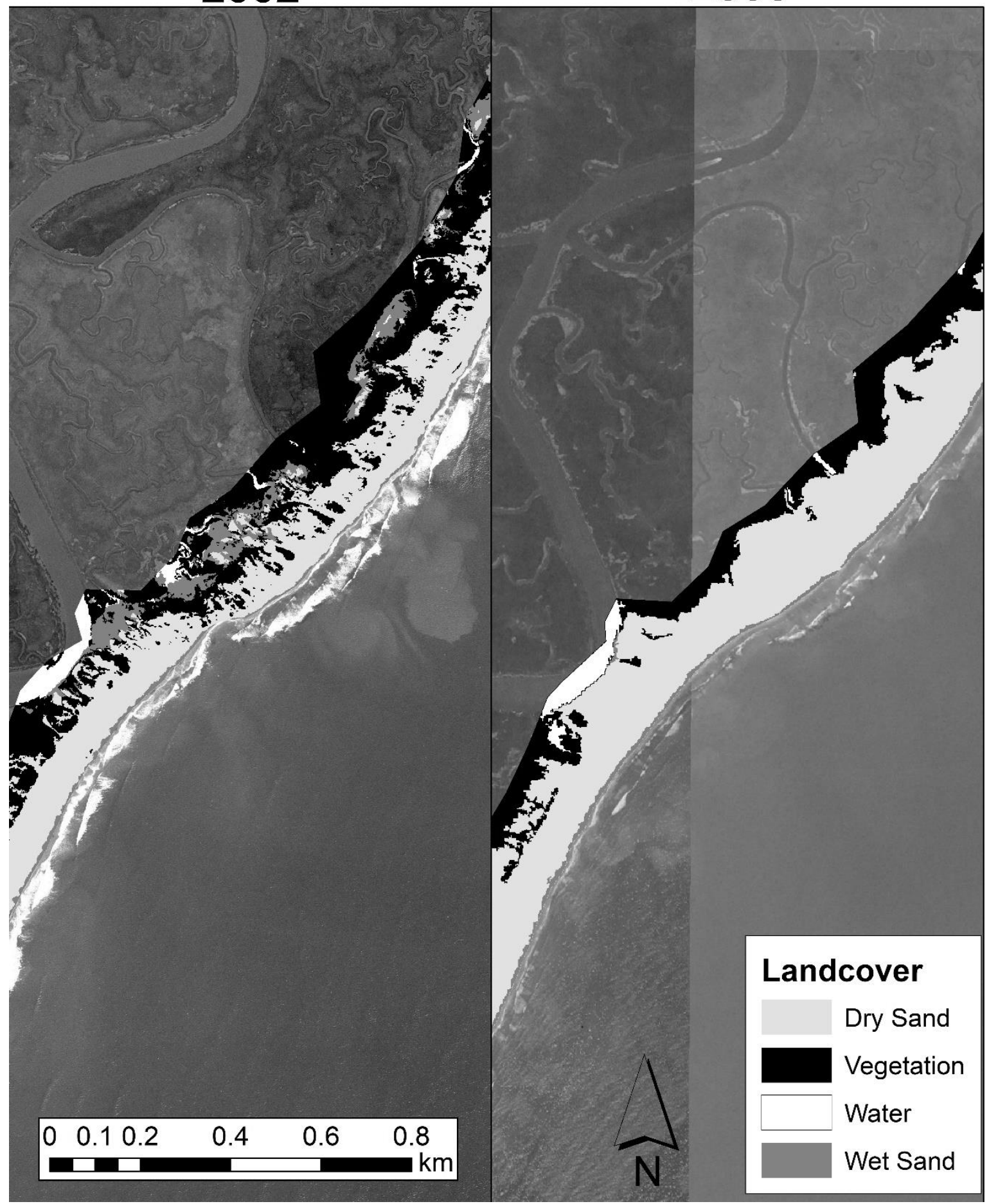

Figure A1.2 Portion of Metompkin Island classification from 2002 (left) and 2005 (right). Classification from eCognition overlaid on respective imagery. Hurricane Isabel occurred in the fall of 2003. 


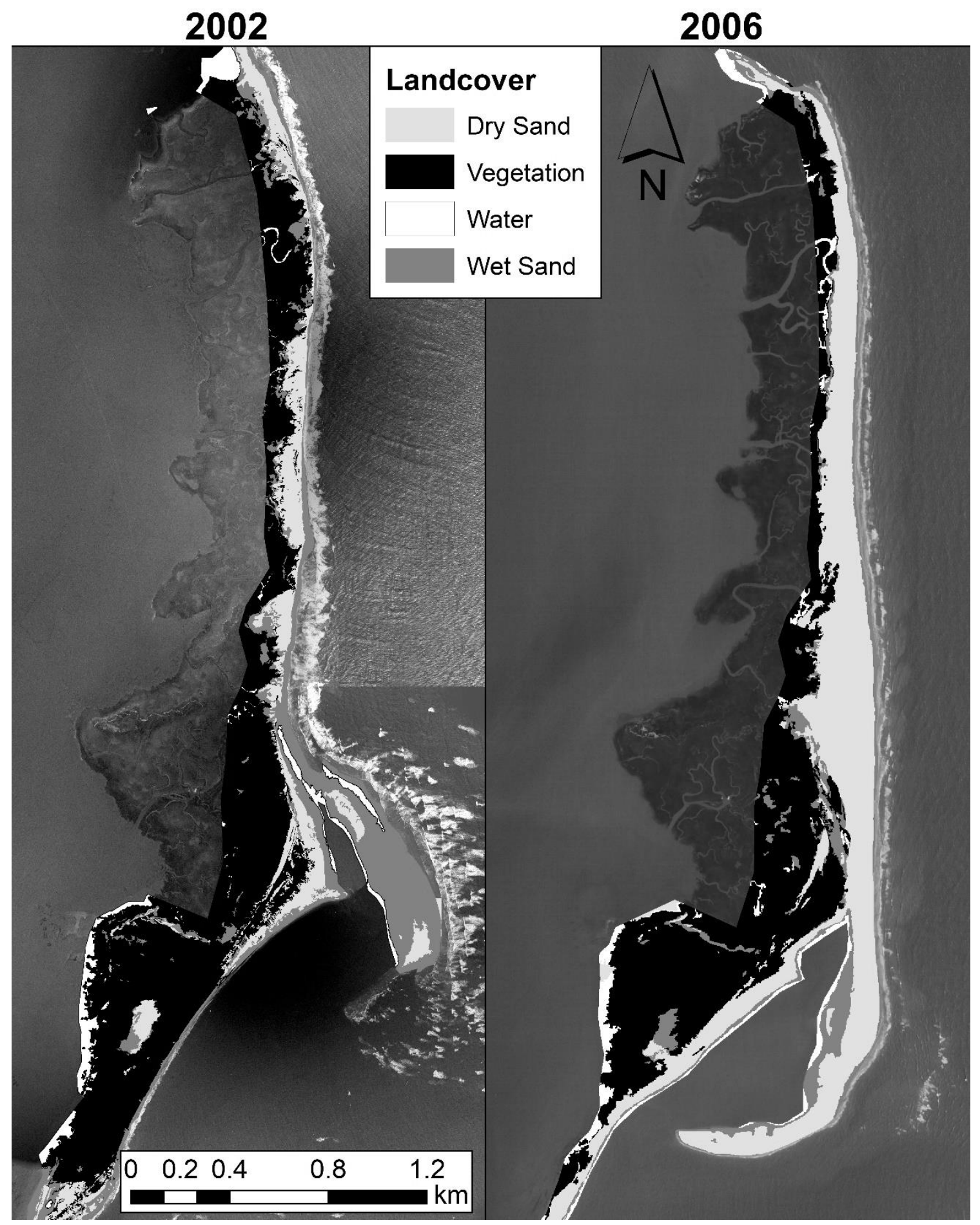

Figure A1.3 Wreck Island classification from 2002 (left) and 2006 (right). Classification from eCognition overlaid on respective imagery. Hurricane Isabel occurred in the fall of 2003. 